\title{
Making the invisible visible: White preservice teachers explore social inequities with the Critical Web Reader
}

\author{
Julie Rust \\ Christy Wessel-Powell
}

\begin{abstract}
This study seeks to establish the role that empathy-building practices can play in broadening perspectives of predominantly white, middle-class teacher candidates. Using emergent coding and grounded theory, we investigate preservice teachers' online analyses of websites about poverty statistics. Themes emerging from their participation with the Critical Web Reader ${ }^{1}$ included confronting 'whiteness' through a growing empathy, complicating their vision of America as the land of opportunity, and voicing insider/outsider clashes. We conclude by discussing the challenges inherent in social action resulting from the desire to make our world more equitable. We also note implications for teacher education, given the rich diversity of the US educational system.
\end{abstract}

\section{Introduction}

Becoming a teacher is rife with complex identity work (Britzman, 2003) that demands a reconciliation between perspectives of self and future students, alongside a recognition of the inequality that often colors classrooms. There is an ever-growing gap between the demographics of teacher candidates (primarily white, female, middle-class) and the wideranging demographics of their future students (Ladson-Billings, 2005; Rogers, 2013). A valuable preservice teacher education experience, then, involves a close examination of the assumptions and personal backgrounds future teachers carry regarding issues such as social class and race.

Many university teacher-education programs feature a stand-alone "diversity" course to address large cultural gaps that many white, middle-class teacher candidates face once they are thrust into classrooms. Such deliberate courses create space for critical, and often painful, self-reflection and discussion. Teacher candidates commonly report feeling uncomfortable in these spaces, and at times it is difficult to discern at the end of the course whether future teachers simply learn the sanctioned, socially sensitive way to speak to please their professors, or if they have genuinely internalized multiple perspectives and grown through discussions.

Here we explore how one online platform, Critical Web Reader (CWR), can potentially serve as a safe entry point into honest and sensitive reflection in one stand-

\footnotetext{
1 This research was supported by funding from the Indiana University School of Education for the Critical Web Reader project (http://cwr.indiana.edu/). Co-principal investigator included Dr. James Damico and Dr. Tarajean Yazzie-Mintz.
} 
alone diversity course. By guiding students to reflect independently on quantitative information about social class from various websites, the CWR fosters preliminary imaginative engagement and empathy in these future teachers. Through this study, we examine the affordances and limitations of these exercises for majority-white preservice teachers with limited access to diverse communities.

\section{Literature Review}

Greene (2007) speaks poignantly about "ethical imagination," which empowers us to "recognize the familiar in the stranger" and imbues us with "the ability to try to see through someone else's eyes, the ability to reach out" (p. 32). It is in the arena of ethical philosophy where taken-for-granted assumptions or "prereflective understandings" (Kerdeman, 1998), and empathic response (Hoffman, 2000) build a bridge to true learning. Building empathy for traditionally disenfranchised groups is of central concern, since

[i]f one empathized with this group, this could underlie the motivation for adopting political ideologies centered around alleviation of the group's plight. [It is] also an internal motive basis for accepting a system of distributing society's resources that helps the least advantaged even at some cost to oneself. (Hoffman, 2000, p. 86)

Though empathy for diverse communities is a crucial quality for preservice teachers to develop, it is an elusive quality to "teach" or foster in preservice teacher programs. There is an entire body of research on manifestations of whiteness in teacher education programs, both domestically (McIntyre, 1997; Sleeter, 2001) and internationally in countries similar to the US in terms of histories of racial tensions, such as Australia (Aveling, 2012). The overwhelming majority of this work focuses on white preservice teachers, and how they sort through (or more often, fall short of) making sense of their own identities in relation to those with less power. This task is most often approached in class through readings, class discussions, and/or reflections on field experiences.

Often, critical literacy activities are employed as entry points to such conversations to encourage position-taking (Rogers, 2013), particularly when most of the preservice teachers involved are white and middle-class; for example, inviting preservice teachers to respond to the research published on preservice teachers and whiteness (Laughter, 2011). However, technological tools for preservice teachers' entry into critical conversations on empathy and whiteness have been studied less often. Our research addresses this gap in the literature. We believe CWR has utility in majority-white preservice teacher classrooms in particular, as an additional introductory critical literacy tool.

\section{Theoretical Framework}

We approach our interpretations of student responses to race and class in the context of CWR activities through a "whiteness" lens. Whiteness theorizes power relationships between people in positions of historical dominance (e.g., white, male, affluent, Englishspeaking) and historically marginalized people (e.g., racial and ethnic minorities, female, poor, non-English-speaking). Sources of social inequities are often invisible to those in relative positions of power, so engaging with whiteness means digging into complex and 
often personally painful conversations. Disassociation from engaging fully or refusing responsibility for one's role are common responses (Lazarre, 1997; Lewis, 2004).

Although the process may be painful or overwhelming, it is particularly important for preservice teachers (Aveling, 2012; McIntyre, 1997). Whiteness is often manifested in schools through curriculum (Rodriguez, 1998; Spring, 1998; Woodson, 1990); academic tracking or 'giftedness' criteria (Staiger, 2004); normative institutional practices (Hurd, 2008; Lewis, 2003; Tatum, 2003); student perceptions of ability; or student-teacher relations (Castigo, 2008; Hurd, 2008; Staiger, 2004). Manifestations of whiteness are also often intimately linked with economic disparities and legacies of poverty (Lipsitz, 2006; McClaren, 1996). In order for preservice teachers to combat these injustices for and with their students in the context of their future classrooms, critical self-reflection on personal involvement in and positioning with regard to these issues is essential.

It is our hope that by engaging preservice teachers meaningfully in critical literacy practices (Janks, 2000; McLaughlin \& DeVoogd, 2004) that confront race and poverty directly, we can support white, middle-class participants in particular in interrogating multiple viewpoints and "disrupting the commonplace, focusing on sociopolitical issues, and taking action promoting social justice" (Lewison, Flint, \& Sluys, 2008) in their own future classrooms. We believe that asking preservice teachers to begin this critical work by reviewing web resources via CWR is an introductory step to building an awareness that should eventually lead to long-term, productive action (Behrman, 2006; Poyntz, 2006). In part, this study gauges how effective such preliminary steps can realistically be, given semester time constraints and social limitations in a majority-white university setting.

\section{Context \& Participants}

In the fall of 2008, we gathered Critical Web Reader student responses for one required, semester-long course at a large Midwestern university, called "Elementary Education for a Pluralistic Society." The university's School of Education student population was 83-93\% white and only $15 \%$ low socioeconomic status (Shedd, 2012). Utilizing a powerful web tool called the Critical Web Reader, students discovered and critiqued both themselves and the sources they read online. Because of the relative lack of racial and socioeconomic diversity within the class of teacher candidates, CWR was used as an effective way to initiate discussions about social class and the very real existence of poverty with predominantly young, white, middle-class to affluent students.

This study draws upon the responses of fourteen undergraduate elementary preservice teacher participants to a CWR activity entitled, "Examining the Numbers about Social Class" (see Figure 1 below). The CWR is a "a set of easy-to-use online tools designed to help address 21st century teaching and learning challenges" that "guides students to carefully and critically evaluate and read any source of information on the Internet" (Critical Web Reader). A flexible template, CWR allows instructors to create theme-based activities for students that involve looking reflectively at the wide array of resources available on the Internet. Once students have perused the resources (articles, charts, songs, movies, images) to which the activity links them, they look carefully at each site through a variety of lenses (such as descriptive, academic, critical, or reflexive) that ask them to 
answer specific questions (see Figure 2). Student contributions are then saved for instructors to examine, assess, or share with the class.

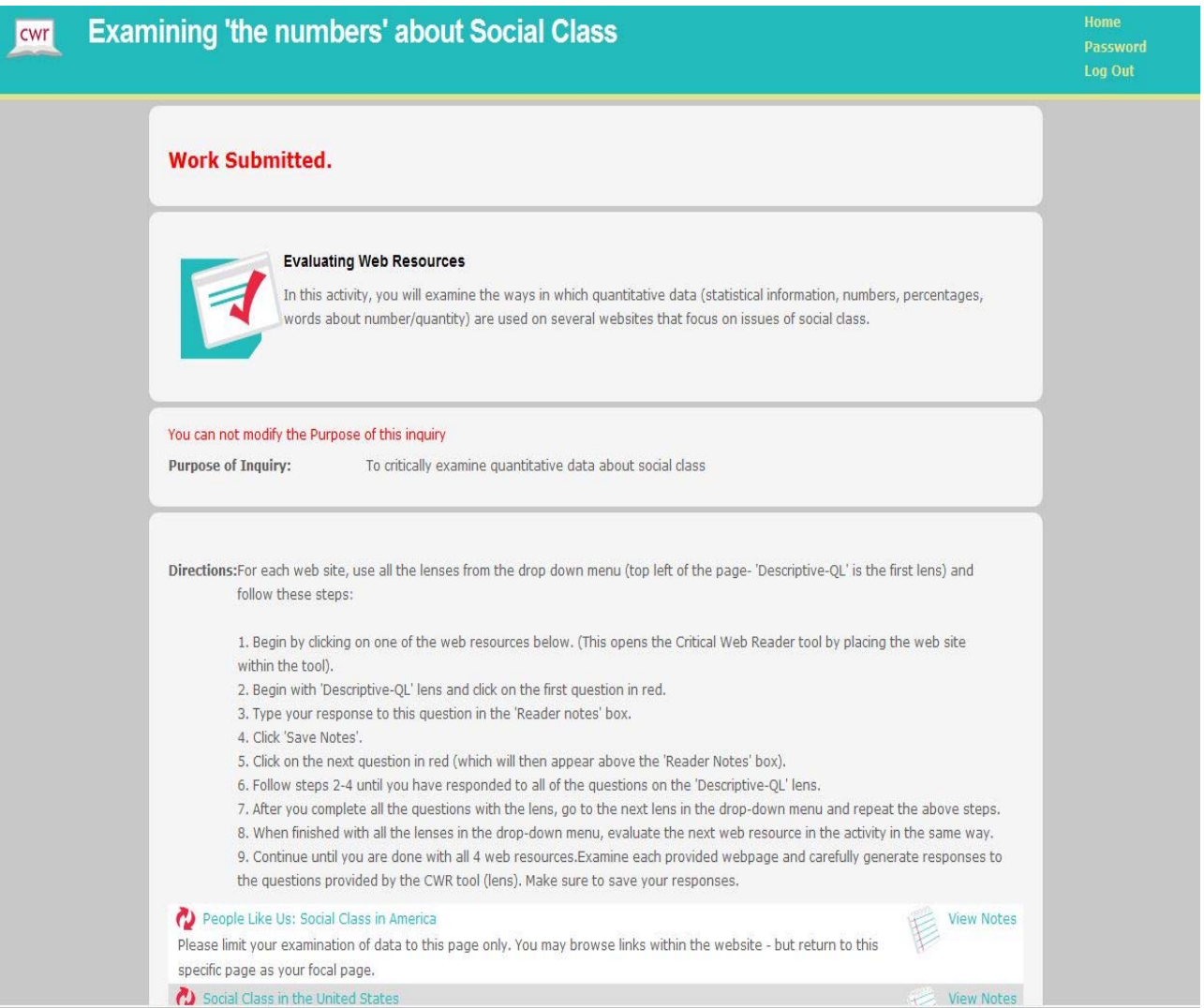

Figure 1. CWR Introduction Page

\section{Descriptive-QL}

- What do I know and believe about this topic?

- What quantitative data is used on this site?
o statistics
o visual representations

- How and when was this data collected?

- What does the site tell me about the:
o author
o sponsor
o intended audience

- Is the site reliable or not? Explain.

Academic-QL 
- What main claim or claims does the author make?

- How is quantitative data used as evidence to support claims?

- Are the claims and quantitative evidence convincing? Explain.

- Are there other possible explanations for the data presented? Explain.

\section{Critical-QL}

- What does this site want me to think, believe or do?

- What techniques are used to influence me?

o Generalities

o Loaded questions

o Biased sample

- Emotional appeals

- Distorted visual representations

- Omitted variable

o Are the techniques convincing? Explain.

Reflexive-QL

- What affects the way I read this quantitative data?

- My values, opinions, emotions

o My background, culture

o My familiarity with quantitative data

- How might people with different experiences and knowledge read this site?

- What questions do I have about the quantitative data on this site?

\section{Figure 2. Critical Web Reader Lenses and Questions}

Today's preservice teachers are likely to encounter a spectrum of student social class backgrounds that may vary widely from their own, so tackling social class in the "diversity" course is vitally important. The first site on the CWR Social Class Activity designed by the instructor features Wikipedia, offering a broad overview of "Social Class in the United States" (http://en.wikipedia.org/wiki/Social class in the United States) (Figure 3). There, students were asked to examine their beliefs about sources like Wikipedia, as well as how a collective group of authors defines social class in the US. 


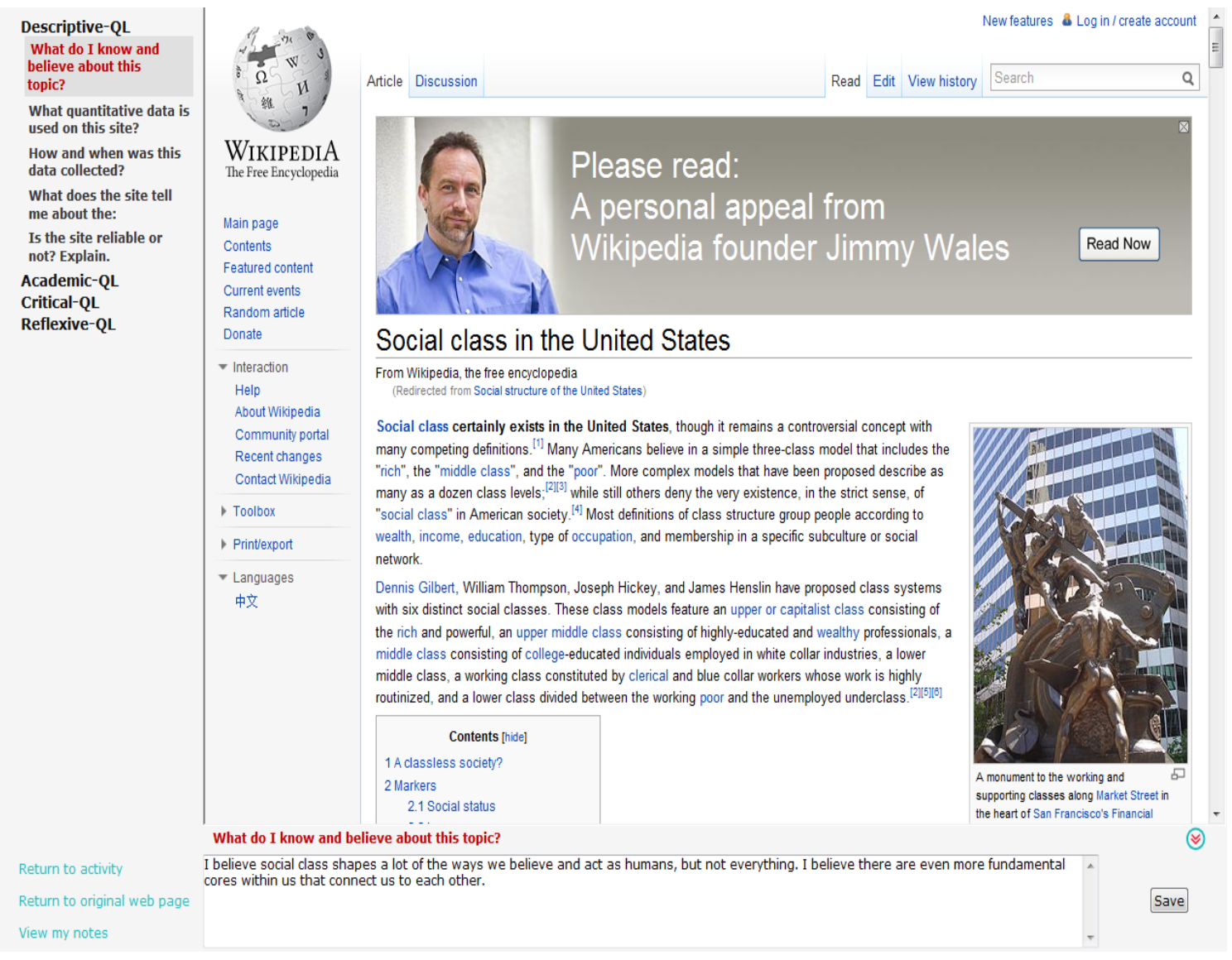

Figure 3. Website 1

Next, teacher candidates were directed to a PBS site entitled "People Like Us" (http://www.pbs.org/peoplelikeus/resources/index.html) (Figure 4) that included a list of decontextualized statistics. 


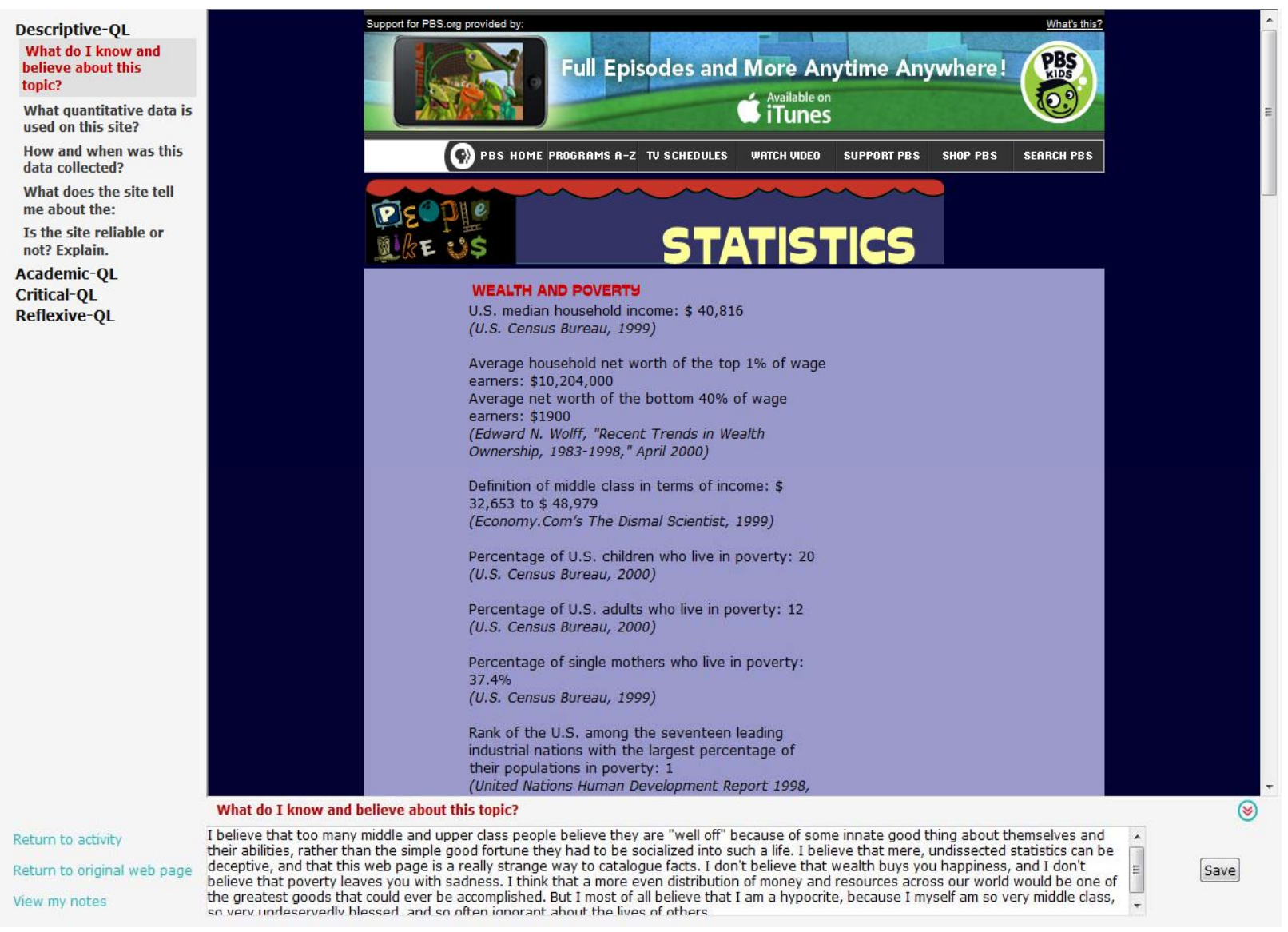

Figure 4. Website 2

Bank

Then came a site on "Understanding Poverty" (Figure 5), sponsored by the World (http://web.worldbank.org/WBSITE/EXTERNAL/TOPICS/EXTPOVERTY/0,menuPK:3369 98 pagePK:149018 piPK:149093 theSitePK:336992,00.html), chosen by the instructor to help students think critically about different organizations with an investment in poverty. 

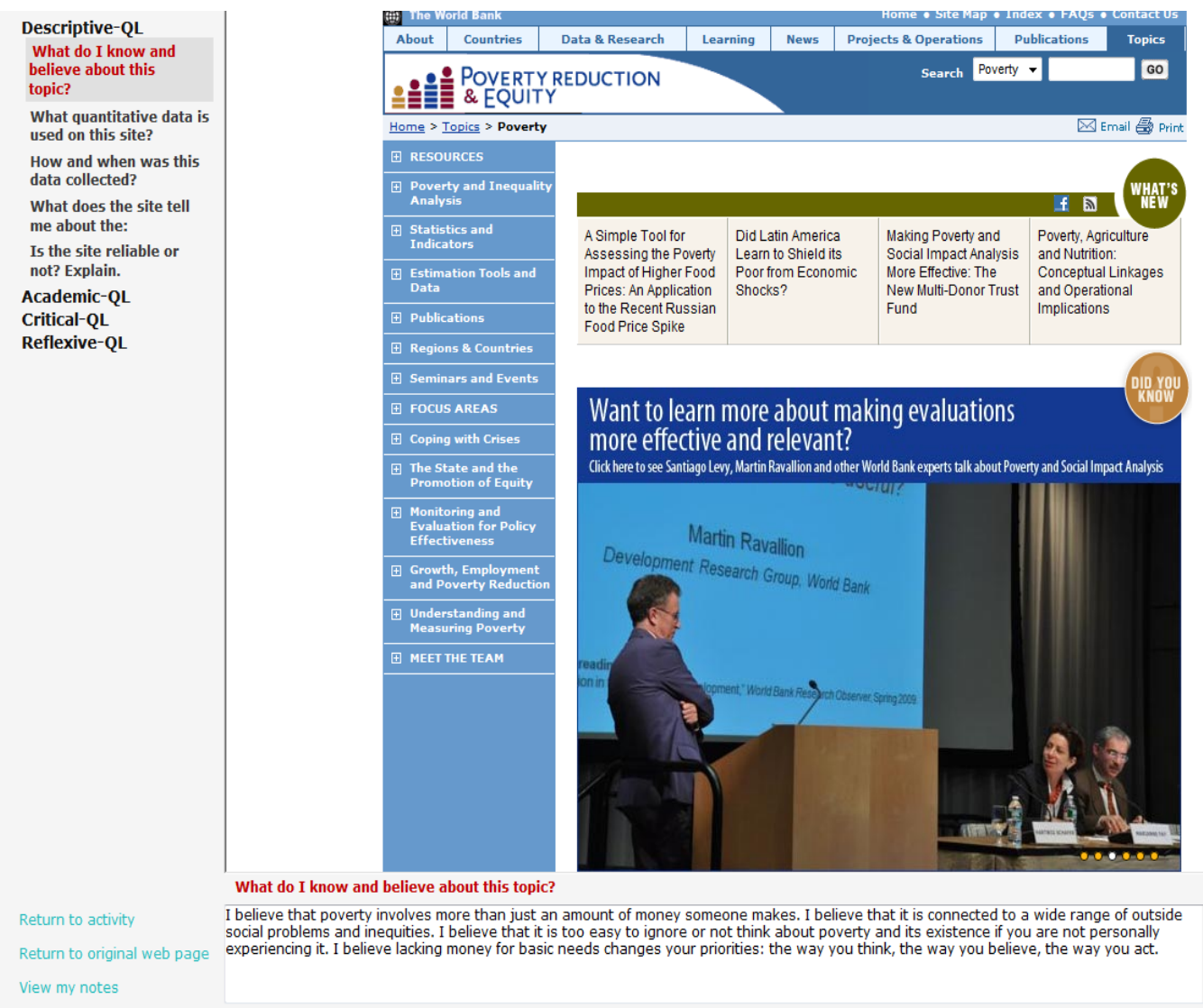

\section{Figure 5. Website 3}

Finally, students ended their journey with a look at the Statewide NCCP Demographics of Poor Children (http://www.nccp.org/profiles/IN_profile_7.html) (Figure 6 ) in order to ground the conversation in the context of the university and the community. 


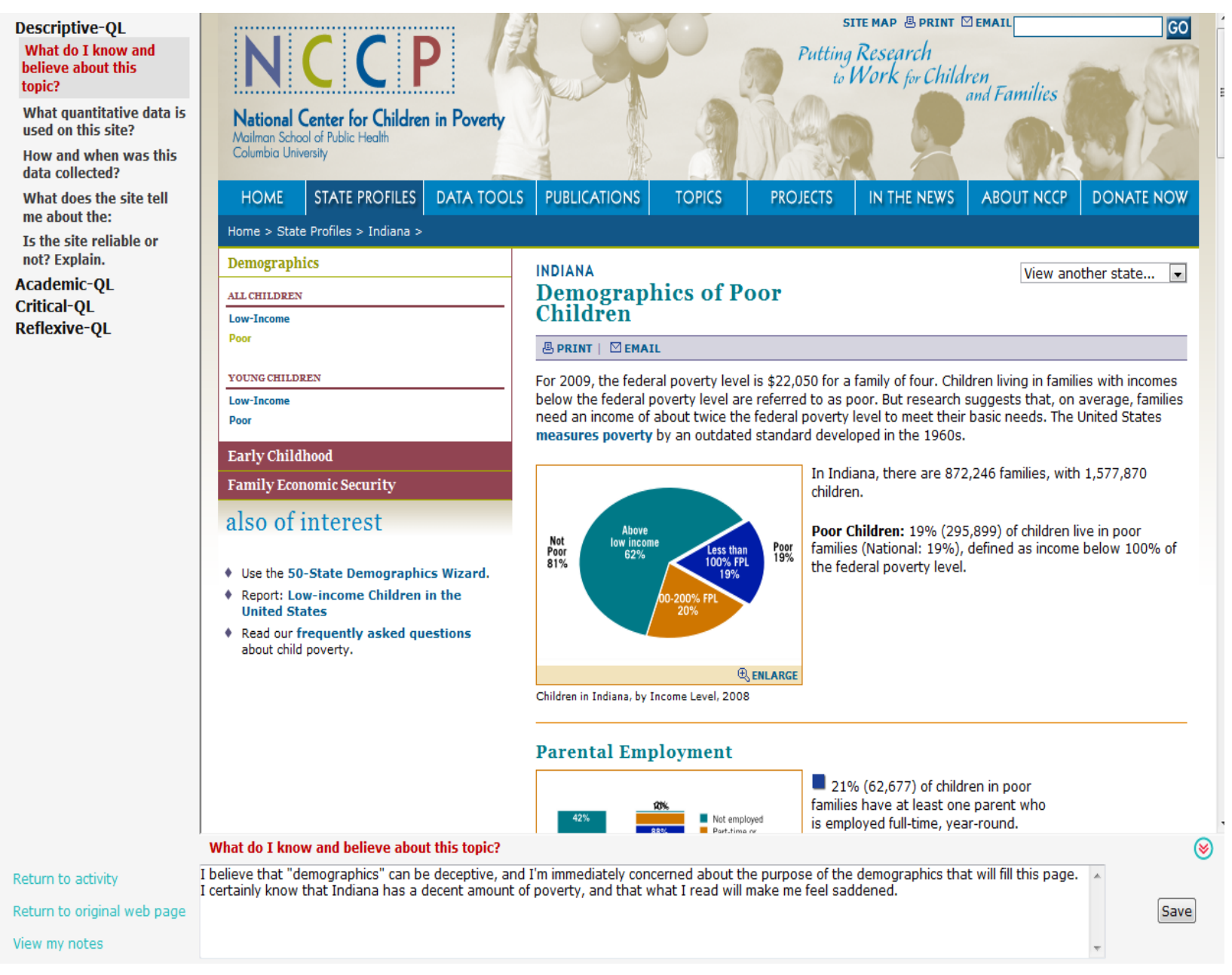

Figure 6. Website 4

While visiting each website (focusing on only one site each week), students contributed answers to questions that focused on four distinct ways of making meaning. The descriptive lens pointed students to look carefully at the website itself, asking questions such as, "How and when was this data collected?" The academic lens called for a more analytical mindset, asking, for example, "Are the claims and quantitative evidence convincing?" The critical lens, among several questions, asked students, "What techniques are used to convince me?" Finally, the reflexive lens provided a space to investigate such thoughts as "What affects the way that I read this quantitative data?" and "How might people with different experiences and knowledge read this site?" These lenses seemed to serve as critical ethical scaffolds as they pointed students to question and challenge both the texts they encounter and the personal reactions they experience.

Because of the tedious nature of each thorough set of questions, students were assigned only one website each week. At the end of the six-week unit, they engaged in a Critical Web Reader debriefing during whole-class discussion. Throughout the exercise, students were encouraged to share their responses with a partner and have brief discussions. These seemingly objective sources of information proved to be a singularly 
illuminating way to gain a glimpse into how preservice teachers perceive "number" data in terms of social class. Students, therefore, made sense of social class privately at first, and then transitioned gradually to more collaborative forms of meaning-making, thus providing a safe, judgment-free place for students to honestly reflect on their initial, personal beliefs. Furthermore, it gave them thoughts to draw upon, defend, or reshape during the wholeclass discussion, during which clashing visions of "the good life" (R. Kunzman, personal communication, October 2010) directly confronted each other.

Our analysis looks more closely at student online comments to interrogate the nature of this critical literacy development. Specifically, we are interested in how students referenced, ignored, or displayed notions of whiteness and empathy in those comments. It is important to note that although this study critically highlights the attitudes that these fourteen teacher candidates had regarding issues of social class and inequality, we want to avoid foregrounding their evolving beliefs through a deficit lens, and also avoid perceiving them as a homogenous group themselves (Laughter, 2011). Instead, we view the sometimes problematic understandings expressed through their participation with the CWR steps in their individual journeys, not as faulty final destinations.

\section{Methods}

Our central research question is, how do preservice teachers reflect on whiteness and react empathically when critically analyzing online texts about social class? In order to explore this, we gathered CWR response data from the classroom of 14 preservice teachers as described above. An emergent coding approach, with categories such as "belief" or "tension," guided analysis of student responses, making use of procedures associated with building grounded theory (Corbin \& Strauss, 2008). We then drew conclusions on the success and limitations of using CWR to engage with diversity issues with majority-white preservice teachers by revisiting the literature on empathy and, most centrally, whiteness. By iteratively discussing interpretations of student responses, we refined three major categories of student response themes that were the most prominent.

Through analyzing CWR responses from these 14 students, and integrating theory regarding whiteness and empathy-building in the classroom, we hope to illuminate how CWR's critical literacy emphasis helps foster ethical reflection regarding diverse perspectives, and to what extent. Secondary questions that surfaced during data analysis included the following:

- How can CWR activities and diverse ranges of online texts actually add a myriad of perspectives to the classroom?

- How is a student's sense of empathy and imaginative engagement shaped through CWR participation?

- What affordances and limitations exist when using CWR to begin critical conversations about race and class within the constraints of a single semester-long course?

\section{Results}

The majority of student responses fell into roughly three thematic categories: EmpathyBuilding, Land of Opportunity, and Insider/Outsider Clashes. These categories or themes 
are described in detail below, and illustrated with representative comments from the students themselves. We feel it imperative, however, to contextualize our findings first, with an explicit acknowledgment of what students bring to critical conversations like these in terms of personal identities, beliefs, and background experiences that shape their participation.

\section{Believe . . .}

I know that there is a lot of inequality due to race, gender, and education. I do not believe that people are in poverty because they do not work hard enough. I also do not believe that those with the most wealth are the hardest workers. (Becky)

Students, of course, begin the identity-building and meaning-making processes long before they enter our classroom doors. If we are determined to see young people as "agents, not just patients" (Pritchard, 1996), it is vital to pay real attention to the beliefs, experiences, and attitudes that students already possess, even before engaging in the work of the classroom. The Critical Web Reader makes this explicit by directly asking, before even delving into a particular website: "What do I know and believe about this topic?" This activates the "prereflective understanding," taken-for-granted assumptions, that Kerdeman (1998) sees as so vital in leading to further understanding.

Interestingly, although perhaps unsurprisingly, in their initial responses the teacher candidates expressed attitudes and experiences that resonated with much of the content and perspectives presented on the websites. Although this could be because some students first previewed the website before answering any questions, because other in-class discussions about social class ensued simultaneously, or because students were engaging in a certain level of "teacher-pleasing," this also could be attributed to the fact that even our white, middle-class students may come equipped with funds of knowledge that could be helpful in a classroom examining issues of diversity.

One of the most common thoughts communicated initially by students was the idea that poverty is a huge problem that exists on both local and international scales. But perhaps the most recurring comment focuses on the unfairness of our current social system. John, inferring that reality does not currently match up with the ideal, states, "I believe that pay should be based on hard work and experience." Sam points out, "I know that there is a white (male) advantage in our culture." Sarah asserts, "It is not fair to the children, because they had no choice and are not responsible for any of their struggles or conditions." Even these preliminary reflections allude to an acknowledgement of an inherently unequal system perpetuated by whiteness.

Just one well-intentioned comment reveals an entirely divergent understanding: "I believe that social class is not important to me, and I also believe that is should not matter to anybody. Why do we have to group people as different from each other?" (Carrie). Although it is unknown whether this prereflective understanding evolved during the course of the semester, the themes expressed here echo as honest portrayals of a student's frustration, perhaps with a course on diversity in general. Carrie's words are undoubtedly well intentioned, and most likely resonate with the underlying attitudes of many preservice teachers thrust into the required diversity class. When explicit reflection on diverse experiences and backgrounds is seen as more divisive than community-building or 
perspective-broadening, a student is unlikely glean as much as possible from such an experience. With this in mind, we move forward to describe further iterations of reflective comments, as the CRW activity moved forward over the course of the semester. First, we examine the nature of students' empathic displays.

\section{Empathy-Building}

"I have said time and time again about how I feel bad about this ... I've been a kid myself and I hate the thought of children suffering ... yes, I feel guilty." (Peter)

Many students empathized with the suffering represented by the statistics listed on these websites, sometimes to the point of articulating personal distress and guilt, or even empathetic fatigue, as in Peter's comment above. Hoffman (2000) describes empathic distress (often experienced by "helping" professionals, like teachers) as a "metacognitive awareness of experiencing empathy ... [providing a] general sense of how they would feel and how others would feel in a similar situation" (p. 63). He continues, "Victims need not be present for empathy to be aroused ... [it] can be aroused when they imagine victims, read about them, or discuss a political issue" (p. 91). Such empathic position-taking can lead to the adoption of a given political ideology or to personal sacrifice regarding a group's particular plight (p. 86) and is an important first step to unpacking white privilege (McIntosh, 1990).

Our data confirms that images, charts, videos, and articles online were effective starting points for imaginative engagement and perspective-taking that took preservice teachers beyond personal experience. Several CWR contributions, however, revealed a pointed focus on personal guilt, rather than on the plight of those in poverty. One in particular stands out:

My race, my white privilege, along with my survivor's guilt, play out a defensive uneasiness in my emotional state. It jumps around, becoming overly compensating to those who have not had my opportunities. My success-obviously unmerited because of my unfair advantages - wants me to read into everything outside of the person as being a reason for that person's failure. Success and failure are arbitrary to a person's abilities. This all plays into how I read these cold, drab facts. (John)

While John's comment demonstrates an understanding of his role in whiteness, when processing personal issues related to whiteness, personal guilt can be a frustrating roadblock inhibiting individuals from growing toward productive action. For some it can be debilitating, and may even stifle the conversation.

Hoffman (2000) also addresses empathy's limitations: "empathic overarousal" (when empathy morphs into personal distress) and "familiarity" or "here and now" bias. Sarah describes the numbing result of compassion fatigue: "Since I was brought up in a large city, I have been exposed to people from all social classes and have seen people living in poverty on the streets, while wealthy businessmen walk right past them without even flinching." Here, the limitations to empathy are clearly articulated. Such reactions are common in critical conversations on whiteness, particularly for white or nonmarginalized participants (Aveling, 2012; McIntyre, 1997). 
One student displays a way to defend herself against disabling empathy: "My first reaction is to feel bad about how these kids live. Then I try to think about how many can be strong and survive it. That is my way of dealing with feelings" (Donna). Familiarity bias, being most concerned with immediate friends or family members, also surfaced among responses: "I had these feelings of sadness and sympathy when reading the descriptions of poverty. They cause you to think about personal experiences or experiences of others closest to you" (Scott). For students with limited exposure to racial and economic diversity on a daily basis, the tendency to look for personal connection when empathizing with disparity may be limiting. Hoffman is quick to note, however, that these are natural, human ways of responding to our world, and that empathy still does provide the basis for a universal set of ethical principles that demand basic human rights for everyone.

Also notable in relation to the CWR tool, Hoffman (2000) points out that "[v]ictims need not be present for empathy to be aroused in an individual ... [it] can be aroused when they imagine victims, read about them, or discuss a political issue ... this is enabled by cognitive development-now we are only limited by our imagination" (p. 91).

It seems, then, that using images, charts, videos, and articles online could very well be the starting point for imaginative engagement and perspective-taking that takes students beyond their own personal situations, even if only as a tentative first step. One illustrative student comment follows: "It makes you think about [how] your own family and you live, and how much you live off of. It made me think of everything I had, and how hard my family has it, in our eyes, to make ends meet. I have no idea what these children are going through!" (Jade).

\section{Land of Opportunity}

"You can be poor and still be able to access education ... you just need to take advantage of your opportunity." (Christopher)

The next theme we routinely observed in student responses regarded the United States as a "Land of Opportunity" in which anyone can succeed if they only try hard enough. Hoffman (2000) describes factors that potentially interfere with empathy: blaming, being self-centered, or minimizing a victim or marginalized person's suffering. These are typical reactions from white or otherwise nonmarginalized people confronting whiteness, because the mechanisms keeping power unbalanced are often unseen and undetectable to those who enjoy relative positions of power. Although all teacher candidates remained respectful of the trials facing those in poverty, some used talk of "opportunity" and "education" to oversimplify what should be a very complicated picture of social class. Their implication in whiteness likely made complex historico-social, -economic and -political factors "invisible" to them (Lipsitz, 2006). Kelly, for instance, after viewing statistics about the correlation between education and poverty level, concluded, "this article does confirm my belief that education and hard work will improve your class standing." Jade hinted at feeling frustrated about advantages poor people are offered in the name of opportunity:

As an American, opportunities are presented to us in several ways. And I feel that those who are rich and considered to be high class may have more opportunities, but those less fortunate get opportunities as well to turn their life around ... While 
my parents and I work hard to achieve our goals, those less fortunate can attend college under $21^{\text {st }}$ century scholars for free. Like I said before, those who are rich may have more opportunities, but those considered poor are presented with opportunities to change their lifestyle.

These reactions demonstrate limitations in CWR's ability to engage students, at this point, in a historically based holistic understanding of the cycle of whiteness and poverty with regard to education and free-market capitalism (Lewis, 2003; Lipsitz, 2006).

Most often, it was apparent that students speaking about how poor people should take advantage of the opportunities offered them held an "outside" perspective as middleor upper-class whites. Narayan (1988) cautions against such assertions, since oppressed insiders have understandings that outsiders cannot possibly have, due to first-hand experience, emotion, and knowledge. Although the student contributions listed above are in no way inherently wrong, they reveal, perhaps, a limited piece of the picture, subtly minimizing the emotional costs of oppression, missing the subtler manifestations of oppression, or failing to see oppression in new contexts. This is also apparent in the assertion several students made that race has nothing to do with poverty, such as the following: "Race is not really the issue, and we need to look more into people as a social class rather than a race" (Christopher). This is problematic given the complex and intertwining relationship between race and class systemically and historically, particularly in the United States (Lipsitz 2006).

Taking responsibility for one's role in the cycle of whiteness is an important, but often painful, step (Lazarre, 1997; McIntosh, 1990; Pixley and Schneider VanDerPloeg, 2000; Woodson, 1990). More nuanced views on the issue, however, also surfaced. Christopher complicated this notion of a "land of opportunity" by displaying some understanding of social reproduction: "[There is l]imited opportunity for underprivileged students from succeeding ... As soon as these kids walk into school, they already have a target on their back as being a failure ... The rich get richer and the poor get poorer."

Insider/outsider perspectives were regularly taken up in student responses, sometimes, though not often, flexibly (i.e., displayed simultaneously by one student), as Christopher demonstrates. John, for example, is a student who also shows an understanding of some systemic inequities that was likely developed before engaging in this class material. Subsequently, we noted his ability to articulate insider perspectives even though he occupies a relatively clear position of power in society as a white, middleclass male. The self-doubt that arises from this negotiation between the familiar and the strange is notable in several student contributions, such as John's below:

I come from the top 5\% financially, and to know that there are almost 10 times as many children now who are impoverished than were those who were more financially secure than me growing up makes me think. So many things I did not have to think about growing up that so many have to be concerned with today. This article reinforces how privileged I was: married parents for the first 13 years of my life, with the same home, being white and suburban. I was meant to succeed. 


\section{Insider/Outsider Clashes}

I grew up in a single parent home, and my mother had no education. I grew up poor just like these graphs show ... in other words, things like this are very convincing because I live it and I believe it. (Angie)

The final theme we noted in student responses positioned participants as either insiders or outsiders to poverty. While some students appeared more cognizant of social class complexity in the US, nearly all students were quick to identify as poverty "insiders" or "outsiders." Students with little poverty experience had a variety of responses. Several described the impossibility of fully grasping the issue, since those who have never been in poverty "may understand that it is an issue, but since they have no experience they cannot place themselves in the shoes of a person who lives in poverty" (Becky). Others found it important to point out that no one has it that easy: "With our stock market the way it is, even our upper class people are struggling” (Angie).

Those expressing a more "insider view" of poverty also added a range of comments to the conversation. One student waxed eloquent about the unfairness of class stratification, since "all jobs are necessary for the functioning and well-being of the society" (John). Several students, referring to data about factors leading to and resulting from poverty, reacted defensively, as is common in critical whiteness engagement and identity reformation (Lewis, 2004). For instance, Becky writes, "I did come from a single mother, and I am fine. Many parents of these kids may be scumbags, missing, or dead, and that could affect them much more than a SIMPLE divorce." Another similarly inspired student points out that not all poor people are subject to an inevitably unhappy existence:

I grew up poor, and my mother and I had to work hard for everything we had. Therefore, I may get frustrated when I hear about an argument being made about someone being poor being the reason of their tribulations. However, I grew up in a small town with good morals and ethics and a parent that cared for me. (Angie)

The real question becomes, then, is it worthwhile to "work together across difference," as Narayan (1998) calls for? Is communication and understanding reachable between these insiders and outsiders? Several students, like Jade, find this a difficult proposition, since they see irreconcilable differences in perspective: "Whatever you take out of the site depends on who you are, your point of view, and past and current knowledge of the subject" (Jade).

Most students conceive different understandings of social class to be predominantly based on one's social class membership. Kelly confidently categorizes the way each social class might see the issue:

Those growing up in poverty will feel the rest of the people have a big advantage over them on the ladder of success. Middle-income people should have similar feelings to me that we need to help the lower-income people more. The wealthy population might believe that they are entitled to more than the rest of society, so they might not see anything wrong with these statistics. 
Waldron (1996) seeks to complicate these arbitrary divisions by emphasizing that our hybridized identities go beyond distinct categories and class or cultural memberships. In his eyes, it is just such artificial generalizations about various groups that can arise from well-intentioned multicultural curricula. This is a particular danger in the context of discussions pertaining to whiteness that take place without nonmarginalized people represented. Pedagogically, then, it becomes essential to complicate neatly drawn categories and distinctions surrounding assumed identities, beliefs, and experiences. If students are able to find common ground between various social classes alongside their differences, perhaps a conversation can really begin to take place.

\section{Action or Inaction? "Seeing” Whiteness}

Given the time constraints of a semester-long course, we found that CWR effectively initiated tough conversations on poverty and race for white preservice teachers, but as a small first step to a larger engagement needed to sustain change. Though participants sometimes experienced shock, pain, or surprise, these feelings were necessary to begin to understand and confront their personal role in whiteness. Voicing unsettled responses is typical but productive in whiteness conversations (Carter et al., 2007; McIntyre, 1997) because participants are more likely to act afterward (Kerdeman, 1999). Kelly explains, "I believe this article raises more questions than actually gives answers ... for me, this article actually makes me wonder more about what is true and what is not, and might make me want to do research of my own to figure it out."

Some directly related their urge to action to the empathy the sites triggered: "I feel really bad for poor people right now and feel the need to do something to help" (Carrie). Notably, however, most of the vows to take action that students made were vague. Carrie continued on to say, "I believe that somehow, someway, we should take steps to try and end poverty or at least contain it." While the tone is admirable, the lack of specificity lends doubt to whether any change in action or behavior will really result. Peter similarly complicates a social action response to the data he encountered on CWR, but in a more specific and nuanced way:

After I feel bad about it, it [makes me want] to go out and join the cause against poverty. Honestly, though, this site annoys me. It reminds me of the people who stand outside the [campus building] handing me small slips of paper and asking me to take a minute to stop global warming. It's going to a take a lot more than a minute, and this going to take a lot more than just me.

Pushing students beyond empathy and into action requires regular opportunities to talk about whiteness and to interact in person with historically marginalized people. It also requires humility, consciousness, an open mind, and a long-term commitment. A semesterlong "diversity" course with online CWR activities that open up productive conversations is a good start, but only a first step in building a teacher toolkit of self-awareness, background knowledge, and a willingness to reach out to marginalized people while respecting their expertise.

While many students discussed being moved to action, it is also important to note the several responses that indicate a sense of hopelessness or a lack of change in 
understanding. Hoffman (2000) might attribute these to self-centeredness or even empathic overarousal. Some students speak of poverty as inevitable, "a big circle that will just keep continuing over time without a change in helping underprivileged students" (Christopher). Others feel the need to point out the unrealistic nature of most potential solutions to the problem: "I know that poverty exists all over the world, and it is a sad thing. At the same time, it seems impossible to fight when people are naturally greedy ... While this is a fine cause, it seems impossible" (Peter). Scott, asserting his "functionalist view," adds, "No matter what, there will be unemployment, which inevitably leads to poverty. We cannot provide everyone in the nation with jobs; there are not enough of them." Others just appear to be unmoved: "I am able to regard the data without an overly surprised feeling" (Patrick). Jade goes so far as to explain why she chooses to ignore the data and the intended impact of the statistics:

The techniques are not convincing to me as a reader. I have knowledge of social status and financial status, and I feel sad that it is sad that there are so many children who are less fortunate, but even more I feel it is sad that as a parent one wouldn't strive harder to make things better for his/her family.

Kelly adds the disheartening comment: "I do not really feel motivated to do anything, so I hope the article doesn't want me to do anything." Whether her lack of motivation stems from not understanding the problem, not feeling empathy for others outside of her circle, or as a defense mechanism to avoid feeling empathic overarousal is not clear.

\section{Class Discussion: Ethical Inquiry}

Although the story might end here, the instructor in this class viewed CWR participation as just a way to begin the conversation. The technology and the websites without reflection could potentially result in just another reaffirmation of previously held opinions. The CWR debrief classroom discussion resulting from the six-week website exploration is the space where authentic community inquiry occurs around the question "What is social class?" Such a discussion format is far from confrontational debate, and revolves around a cooperative meaning-making process, one that resonates with Tannen's (1998) preference for dialogue and Parker's (2003) description of valuable discussion, in which students discover their own sense of justice through dialogic interactions.

Much of the groundwork for discussion has occurred during personal CWR participation, since, as Parker (2003) points out, "Reversibility is an ideal form of reciprocity and means changing places with-perspective-taking, genuine exchange. It requires inclusion, dialogue, and imagination" (p. 86). In essence, then, teacher candidates are better equipped to discuss issues of social class with a diverse group of students once they have been exposed to a variety of perspectives through the websites.

Being serious about quality student discussion participation is part of Simon's (2001) vision of school-wide inquiry for moral education, moving teachers beyond a vision of mere pedagogical neutrality. Interestingly, the CWR activity, on its own, presents the potential risks of pedagogical neutrality, namely the inevitability that teachers omit, include, and shape curricular materials, thus remaining unable to be entirely neutral. The 
discussion that ensues, then, is pivotal in opening up a space for the students to dialogue about their findings in a way that can be both responsive and generative.

\section{Implications}

Although our research draws upon the experience of just one class through the limited lens of their virtual contributions to an online activity, we feel it highlights the very real challenges that teacher educators face in enabling future teachers to more clearly see themselves and their future students. While every course undoubtedly provides its own set of issues, challenges, and uncertainties, a course on diversity for teacher candidates must have more than its fair share. Our work finds that the CRW, woven along with other texts, movies, activities, and discussions, has enabled students to begin thinking more broadly about issues that previously may have seemed irrelevant. By perusing quantitative data on social class, reflecting on this data personally and independently on CWR, and debriefing on the experience in a large-group-discussion, these preservice teachers revealed empathy, imaginative engagement, an awareness of their insider/outsider status, understanding, and ethical inquiry. Importantly, students did not emerge from the six weeks with easy answers. The diversity course in many ways accomplished Lewison et al.'s (2002) critical literacy goal of "disrupting the commonplace."

Of course, not every student who leaves the class has grasped the complexity of social class and how it might play out in the classroom. A few most likely left with their previous beliefs affirmed. But the work of class-wide critical-ethical inquiry isn't to indoctrinate, but to help to open up. Whether or not these teacher candidates find a sense of closure or resolution for the big questions raised in their class on diversity may not even be the point. The fact that they spent six weeks wrestling with these big questions, both independently and collaboratively, steeped in a wide range of related resources, points to the hope that they may see the value in critically looking at the big issues and confronting them in their future classrooms. After all, examining deep-seated assumptions, experiencing empathy and imaginative engagement, learning how to speak across differences, fostering real understanding, and engaging in class-wide ethical inquiry seem to be the most authentically educative experiences of all.

More research needs to be done in the ways that technology might foster these important conversations, and more work needs to look honestly at the ways that teachers' use of new media in the classroom may inadvertently work against perspective-broadening goals. The role that the CWR played in our case, as a safe place for students to privately make sense of their own deep-seated reactions and assumptions before engaging in open face-to-face dialogue, seems worth exploring, because it points to a very different way of considering technology implementation in the classroom. Future teachers need to build empathy towards action, to complicate their understandings of America as "the land of opportunity," and to bridge insider/outsider perspectives. Looking critically at the way websites present quantitative data on social class while explicitly hashing out the life experiences and assumptions that color their perspectives is perhaps one potential way in to "seeing whiteness" through the lens of social class. 


\section{References}

Aveling, N. (2012). Critical engagement with whiteness: Beyond lecturing on the evils of racism. In B. Down \& J. Smyth (Eds.), Critical voices in teacher education (pp. 111123). Dordrecht, Neth.: Springer Science Press.

Behrman, E. (2006). Teaching about language, power, and text: A review of classroom practices that support critical literacy. Journal of Adolescent and Adult Literacy, 4(6), 490-498.

Britzman, D. (2003). Practice makes practice. Albany: State University of New York Press.

Carter, S., Honeyford, M., McKaskie, D., Guthrie, F., Mahoney, S., \& Carter, G. D. (2007). What do you mean by whiteness? A professor, four doctoral students, and a student affairs administrator explore whiteness. The College Student Affairs Journal, 26(2), 152-170.

Castigo, A. (2008). “I don't want to hear that!” Legitimating whiteness through silence in schools. Anthropology \& Education Quarterly, 39(3), 314-333.

Corbin, J., \& Strauss, A. (2008). Basics of qualitative research (3rd ed.). Los Angeles, CA: Sage.

Critical Web Reader. (2010). Retrieved from http://cwr.indiana.edu/.

Greene, M. (2007). Art and imagination: Overcoming a desperate stasis. In A. C. Ornstein, E. Pajak, \& S. B. Ornstein (Eds.), Contemporary issues in curriculum (pp. 32-38). Boston, MA: Pearson.

Hoffman, M. (2000). Empathy and moral development: Implications for caring and justice. Cambridge, UK: Cambridge University Press.

Hurd, C. (2008). Cinco de mayo, normative whiteness, and the marginalization of Mexicandescent students. Anthropology \& Education Quarterly, 39(3), 293-313.

Janks, H. (2000). Domination, access, diversity, and design: A synthesis for critical literacy education. Educational Review, 52(2), 175-184.

Kerdeman, D. (1998). Between Interlochen and Idaho: Hermeneutics and education for understanding. In S. Tozer (Ed.), Philosophy of education 1998 (pp. 272-279). Urbana, IL: Philosophy of Education Society.

Ladson-Billings, G. J. (2005). Is the team all right? Diversity and teacher education. Journal of Teacher Education, 56(2), 229-234.

Laughter, J. (2011). Rethinking assumptions of demographic privilege: Diversity among white preservice teachers. Teaching and Teacher Education, 27(1), 43-50.

Lazarre, J. (1997). Beyond the whiteness of whiteness: Memoir of a white mother of a black son. Durham, NC: Duke University Press.

Lewis, A. (2003). Race in the school yard: Negotiating the color line in classrooms and communities. New Brunswick, NJ: Rutgers University Press.

Lewis, A. E. (2004). "What group?" Studying whites and whiteness in the era of "colorblindness." Sociological Theory, 22(4), 623-646. 
Lewison, M., Flint, A., \& Sluys, K. (2002). Taking on critical literacy: The journey of newcomers and novices. Language Arts, 79(5), 382-392.

Lipsitz, G. (2006). The possessive investment in whiteness: How white people profit from identity politics. Philadelphia, PA: Temple University Press.

McClaren, P. (1996). Whiteness is ... In J. L. Kinchelos, S. Steinberg, N. Rodriguez, \& R. Chennault (Eds.), White reign: Deploying whiteness in America. New York, NY: St. Martin's Press.

McIntosh, P. (1990). White privilege: Unpacking the invisible knapsack. Independent School, 49, 31-35.

McIntyre, A. (1997). Making meaning of whiteness: Exploring the racial identity of white teachers. Albany, NY: State University of New York Press.

McLaughlin, M., \& DeVoogd, G. (2004). Critical literacy as comprehension: Expanding reader response. Journal of Adolescent and Adult Literacy, 48(1), 52-62.

Narayan, U. (1998). Working together across difference: Some considerations on emotions and political practice. Hypatia, 3(2), 31-47.

Parker, W. C. (2003). Teaching democracy: Unity and diversity in public life. New York, NY: Teachers College Press.

Pixley, M., \& Schnieder VanDerPloeg, L. (2000). Learning to see: White. English Education, $32(4), 278-279$.

Poyntz, S. (2006). Independent media, youth agency, and the promise of media education. Canadian Journal of Education, 21(1), 154-175.

Pritchard, M. S. (1996). Reasonable children: Moral education and moral learning. Lawrence, KS: University Press of Kansas.

Rodriguez, N. M. (1998). Emptying the content of whiteness: Toward an understanding of the relation between whiteness and pedagogy. In J. L. Kincheice, S. R. Steinberg, N. M. Rodriguez, \& R. E. Chennault (Eds.), White reign: Deploying whiteness in America (pp. 31-62). New York, NY: St. Martin's Press.

Rogers, R. (2013). Cultivating diversity through critical literacy in teacher education. In C. Kosnik, J. Rowsell, P. Williamson, R. Simon, \& C. Beck (Eds.), Literacy teacher educators: Preparing teachers for a changing world. Boston, MA: Sense Publishers.

Shedd, J. (2012). School of Education Ethnicity by Primary Program. In University Database. Bloomington, IN: Indiana University.

Simon, K. G. (2001). Moral questions in the classroom: How to get kids to think deeply about real life and their schoolwork. New Haven, CT: Yale University Press.

Spring, J. (1998). Education and the rise of the global economy. New York, NY: Routledge.

Sleeter, C. E. (2001). Preparing teachers for culturally diverse schools: Research and the overwhelming presence of whiteness. Journal of Teacher Education, 52(2), 94-106. 
Staiger, A. (2004). Whiteness as giftedness: Racial formation at an urban high school. Social Problems, 51(2): 161-181.

Tannen, D. (1998). The argument culture: Moving from debate to dialogue. New York, NY: Random House.

Tatum, B. D. (2003). Why are all the black kids sitting together in the cafeteria? New York, NY: Basic Books.

Waldron, J. (1996). Multiculturalism and mélange. In R. Fullinwider (Ed.), Public education in a multicultural society: Policy, theory, critique (pp. 90-118). Cambridge, UK: Cambridge University Press.

Woodson, C. (1990). The miseducation of the negro. Trenton, NJ: Africa World Press, Inc. 